\title{
"Telling a past, dreaming a future" (Walter Brueggemann) - Die essensie van die narratiewe pastoraat
}

\author{
J C Müller en J Laas'
}

(Universiteit van Pretoria)

\begin{abstract}
"Telling a past, dreaming a future" - The essence of narrative pastoral counseling

The article examines the possibilities of negotiating the double movement created by living towards the future and dreaming out of the future into the present. Story telling in the pastoral environment is suggested as a means of bringing together the past and the expected future.A circular approach to time can help immensely by bringing together past and future in a meaningful way. This becomes possible in the pastoral environment where there is real understanding between pastor and client through thorough communication and the reframing of the past. The importance of language in understanding and the transformative power of narrative are stressed, as well as Christian hope as the most fundamental way of finding meaning out of the future into the present.
\end{abstract}

\section{IN DIE BEK VAN DIE TIER}

Oom Andries is een en tagtig. Hy is lewenslustig en energiek, maar vandag is dit ' $n$ ander storie. Sy knie-operasie, die pyn, die kankernuus en die klein inperkende kamer, anders as die wydtes en ruimtes van sy plaas, maak hom teneergedruk. Hierdie ding het hom meer gevang as wat hy gedink het. Dalk sal hy nooit weer hier opstaan nie. Hy is hartseer, ongelukkig en besorg oor die toekoms. Toe hy my sien, is hy aangedaan. Sy stem is bewerig en ontneem van die kenmerkende selfvertroue. ' $n$ Traan loop oor sy een wang. Hoe dit gekom het, kan ek nie onthou nie, maar hy was weer aan die vertel: Amper vyftig jaar gelede, het ' $n$ 'tier' verwoesting gesaai onder die boere se vee. "Ons het sy spoor gevat'. Met presiese detail vertel hy van die honde, sy maats, die wind, die bakkie met net twee ratte vorentoe, die terrein, alles. So duidelik dat ek dit kon sien...

"En toe het hy uitgespring, en reg op ons afgepyl. Ek het alles gelyk gedoen: gestop, uitgeklim, my Lee-Metford uitgehaal, aangelê. Daar was nie tyd nie. Met elke sprong het hy gesê ha-ha-ha. Sy bek was

${ }^{1}$ Ds Jockie Laas is ' $n$ student aan die Universiteit van Pretoria en is ingeskryf vir die MDiv in Praktiese Teologie (Pastorale Gesinsterapie). Sy studieleier, met wie hy ook hierdie artikel gesamentlik geskryf het, is prof Julian Müller van dic Departement Praktiese Teologie. 
wyd oop. Sy geel oë het op my geblits. Op dertig voet het ek hom geskiet, reg in sy oop bek, morsdood". Hy bly stil... Ek sit ook oopmond. "Ja Dominee", sê hy nadenkend, vonkeloog, "op my dag was ek "n knap skut".

Hy het beter gevoel, en ek ook...

\section{LAG MET'N TRAAN}

' $n$ Uur later het ek vir Jurgens (3) en Corli (2) by die kleuterskool gaan haal. Juffrou was nog besig om stories te vertel en op die mat het die groepie kinders geskaterlag. Hulle het nie geen aanstaltes gemaak nie, en ek moes geduldig wag dat die storie klaar vertel word. Met die naderkom merk ek dat Jurgens se regterknie sleg nerf-af is. "En dit"? vra ek. "Ek het van die swaai-swaai afgeval, Pappa. Só seer, só seer". Sy knie was stukkend, sy wange nog half nat van die trane, maar sy hart was heel, want stories maak alles beter. Naïef? Kinderlik?

\section{STORIES HIER, STORIES DAAR, STORIES ORAL OOR}

"Like many of my contemporaries, I became disillusioned with the outcomes of social psychological research and theorizing carried out under the guiding postulates of positivism" (Sarbin 1986:ix). Talle wetenskaplikes is toenemend ontnugter en teleurgestel gelaat in die onvermoë van die psigologie en ander geesteswetenskappe om menslike gedrag oortuigend te ontleed, verstaan en te verklaar. Hierbenewens is daar, as deel van die postmodernistiese tydsgees, ' $n$ algemene bevraagtekening van die twyfelagtige antwoorde wat die modernisme op talle terreine probeer gee het, veral met gewaande sekerheid en 'n absolute waarheidsbeskouing. Goudzwaard (1999:16) skryf dat modernisme "'n rasionalistiese geslote wêreld is, " $n$ wêreld sonder antwoorde". Dit is dic analitiese, wetenskaplike, kliniese laboratoriumbestaan. Met sy klem op sukses, op prestasie, op geld en op roem. " $n$ Koue, onmenslike omgewing met baie vaste idees oor hoe mense is, en behoort te wees. Die wetenskapsgroei, kennisontploffing en tegnologiese revolusie het ' $n$ diep versugting gebaar. Mense wil net weer mens wees. Net verstaan word. Gehoor word. In pas met hulle eie tempo kom. Tot sin kom, ja tot verstaan kom. Gerkin (1991:11) praat van "ministry practitioners who are puzzled and concerned", en, in die oorgang van modernisme na postmodernisme, van "a climate of confusion and uncertainty".

Die mensdom rondom die jaar 2000 verkeer in krisis, op soek na groter menslikheid, meer egtheid en eerlikheid sowel as duideliker antwoorde. Die maatskappy KPMG adverteer nie sonder rede sy produk met die woorde: "Never before has so much technology and information been 
available to mankind. Never before has mankind been so utterly confused" nie; en dan sê hulle: "... it is time for clarity." (Finansies en Tegniek, Julie 1999:34). Dit verwoord iets van die frustrasie, agterdog en skeptisisme van die postmodernistiese epistemologie.

Tog is daar ' $n$ nuwe wind wat waai. Minder antwoorde, maar tog ' $n$ ervaring van egtheid.

Die aard van ons bestaan is narratief. $\mathrm{Na}$ ons wese is ons storiemakers, en luisteraars. Ons word gebore met die "ability and desire to express and receive stories" (Webb-Mitchell 1995:219). Van die mees basiese handelinge in die menslike bestaan is om te vertel, te interpreteer, en dit wat geïnterpreteer is, in woorde weer te gee, goedskiks weer in storievorm. Dit is " $n$ onophoudelike, sirkulêre, sosiaal gekonstrueerde proses. "Narrative is crucial in understanding human life for all that we are, and all that we do, and all that we think and feel is based upon stories, both our personal stories and the stories of our significant community" (Webb-Mitchell 1995:215).

Mense van alle tye en kulture het stories gebruik as ' $n$ basiese manier om hulle ervaringe te organiseer en betekenis aan hulle lewens te gee ( $\mathrm{vgl}$ Hermans en Hermans-Jansen 1995:6)

"....as we construct our stories we are sewing together fragments of living in larger wholes. We seek to comprehend through the stories we tell. Story is the natural form we use to put the aspects of experience and life together, to bring what we are living into synthesis, an articulated coherence" (Hoskins and Leseho 1996:246).

Hermans en Hermans-Jansen (1995:6) gebruik die metafoor: "the person as motivated storyteller" en brei uitvoerig en oortuigend daarop uit dat " $n$ mens van nature gretig is om te vertel. Met "Story" word bedoel "just something we tell, although this is part of it, but more basically, the way things happen and the way we grasp them in some kind of pattern". (Hearne 1984:33). Sarbin (1986:9) se definisie beskryf narratief "as a way of organizing episodes, actions and accounts of actions in time and space". Verder skryf hy: "human beings think, perceive, imagine and make moral choices according to narrative structures" (Sarbin 1986:6). Met die vertel van stories neem jy tegelyk jou tydgebonde en ewige bestaan ernstig op. "Gather the folks, tell stories, break bread and drink wine, get moving this is the human task" (Hearne 1984:34).

Storie, verhaal en narratief word vir die doeleindes van hierdie artikel as sinonieme gebruik en in die wydste denkbare sin daarvan. Die nuus, gedigte, geskiedskrywing, vertelling, gesprek, film, teater en talle ander menslike handeling bevat stukke en dele van stories, soms volledige stories. Ons maak hier nie outeur, of werklikheid, of begin en einde of selfs "plot" voorskriftelik vir iets om 'n storie te wees nie. Ook lewenlose 
voorwerpe: 'n foto, ' $n$ huis, is deel van ' $n$ menslike storie en hoewel stom, is dit maar net "storieloos" vir solank die storie nog nie vertel is nie. Elke ding en plek het " $n$ storie. Dit is soos die engel in die klip wat net bevry moet word. Hoewel stories wat op die stoep en voor slaaptyd vir kinders vertel word absoluut deel van ons lewe is, gaan dit nie in die artikel oor méér. In die narratiewe benadering gaan dit om ' $n$ ontginning van ' $n$ persoon of gesin se "master story" (Webb-Mitchell 1995:218).

Die tema "Telling a past, dreaming a future," (Brueggemann 1993:120) verwys na die manier waarop Brueggeman die Christelike leefwyse beskryf. Mens sou die uitdrukking selfs wyer kon sien, as 'n beskrywing van ons hele bestaan (vgl Müller 1998:9). In hierdie stelling gaan dit oor ' $n$ samehang tussen verlede, hede en toekoms. Dit gee uitdrukking aan die wese, die essensie, die hart van die narratiewe benadering. Waar daar kontinuïteit tussen die verlede, deur die hede na die toekoms is, is daar hoop en sekuriteit. Waar dit nie gebeur nie, is daar onsekerheid en spanning, selfs uitsigloosheid. Hoe groter die gaping tussen die "telling" en die "dreaming" word, hoe groter word die spanning en hoe groter is die kans vir patologiese gedrag. Aan die ander kant, waar daar harmonie is tussen gister, vandag en môre, is daar integriteit, gesondheid en volwassenheid (vgl Müller 1998:9). Dit gaan hier oor wesensvrae, ten diepste oor die soeke na sin. En dan moet sekerlik gevra word na wat met sin bedoel word. Wanneer daar ' $n$ samehang is wat aan die geheel van ons bestaan ' $n$ ervaring van betekenis gee, is daar sin. Sin is daarom toekomsbepaald.-Dit kan nie nagejaag word sonder ' $n$ duidelike beeld (verbeelding) van ' $n$ toekomsstorie nie (vgl Müller 1996:27). Vertel veronderstel dit 'n spesifieke verlede en toekoms. Dié van ' $n$ individu. Dit veronderstel die vertel van ' $n$ persoonlike verhaal. Hierdie vertelling vind plaas binne ' $n$ proses, want geen mens kom met ' $n$ enkelvoudige, helder en samehangende verhaal na 'n spreekkamer toe nie. In 'n unieke, dialogiese verhouding van vertroue en in-diepte kommunikasie ontvou hierdie persoonlike verhaal. Die pastor wat ' $n$ narratiewe benadering het, sal dit as sy groot taak sien om te luister na, en om die stories van mense te interpreteer. Die persoon moet uitgenooi, uitgelok, en uitgedaag word om sy storie onbevange en sonder verskonings en weglatings in ' $n$ atmosfeer van openhartige aanvaarding te vertel. Daar moet met erns ag geslaan word op die storie wat vertel word.

"The act of telling always presupposes a dialogical relationship between a teller and a listener. ..we argue that the client's self narrative results from the contributions of both the client and the pastor" (HermansJansen 1995:28). In wisselwerking met mekaar, deur gesprek, word gesamentlik aan ' $n$ self-narratief gebou. Albei dra by tot die proses. Hulle staan komplimentêr teenoor mekaar. Die gespreksgenoot is die kundige oor sy/haar lewensverhaal en die pastor neem deel vanuit ' $n$ ander ervaringswêreld. Die pastor moet hierin sy algemene kennis, mensekennis, lewens- 
ervaring, asook vakkundige kennis, teologies- sowel as psigologiese kennis in diens stel en as medewerker met die verteller 'n situasie skep waarin daar "re-storying" kan plaasvind. Hierdie diep menslike ontboeseming hou groot implikasies in vir beide partye. Die pastor moet waak daarteen om nie te gou verstaan nie, en eerder toelaat dat hy/sy oor die drumpel van die gespreksgenoot se lewe getrek word - en so to geleidelike verstaan kom.

' $n$ Teorie wat hierin ' $n$ groot bydrae lewer en uiters verhelderend is, is Hermans se "Valuation theory". Hy verduidelik die teorie self soos volg (Hermans 1992:363).

"Valuation, entails an active process of meaning construction. A valuation is any unit of meaning that has a positive (pleasant), negative (unpleasant), or ambivalent value in the eyes of the individual. As such, valuation is an open concept and includes anything people find to be of importance in telling their life stories".

Op verskillende plekke, tye en in verskillende omstandighede het sekere persone, sake of dinge so " $n$ indruk op " $n$ individu gemaak dat hy of sy dit belangrik genoeg ag om deel van ' $n$ persoonlike verhaal te word. Hierdie kernstorie van ' $n$ persoon is van die uiterste belang - veral waar die self gesien word as ' $n$ organiserende proses van waardering, is die betekenisecnhede, wat dikwels by wyse van metafoor uitgedruk word, soos pêrels in die gesprek. "Metafore is draers van betekenis. Dit funksioneer om uitdrukking te gee aan menslike ervarings wat op geen ander manier uitgedruk kan word nie. Dit sê meer as wat letterlik gesê sou kon word" (Müller \& Maritz 1998:70). Metafore word nie alleen gebruik om die self te beskryf nie, maar veral om die self te vorm (vgl Hoskins en Leseho 1996:243). Leary (soos aangehaal deur Hoskins en Leseho 1996:243), skryf: "These metaphorical concepts are not simply descriptive: they have also been transformative: Their use has led to changes in human self-reference and hence to human self-consciousness". Die uiters belangrike konsep van persoonlike identiteit, is hier op die spel, naamlik "personel identity, without which I do not know who I am, is at stake in this formative application of narrative art" (Crites 1986:162).

Om goed te onthou is daarom noodsaaklik "The more complete the story, the more integrated the self" (Crites 1996:162). Mens sou kon praat van "Genesende onthou", want om gesond (heilsaam) te kan vergeet, dit eers nodig is om goed te onthou (vgl Müller 1996:119).

Hierdie persoonlike verhaal, word vertel en weer vertel en oor vertel, altyd weer met ander nuanseringe. "In the telling and retelling the images which convey meaning for them begin to emerge with more clarity and integration" (Jensen 1984:222).

In die literatuur oor narratiewe is dit duidelik dat dit altyd gaan om ' $\mathrm{n}$ her-vertel. Daar is nie sprake van ' $n$ eenmalige klaar-vertel nie. Hermans, 
praat van "essentially unfinished stories" (Hermans, in Hermans \& Jansen 1995:111). Veral waar daar ' $n$ blokkasie ontstaan het in die persoonlike verhaal, word her-vertel noodsaaklik. Waar 'n versperring voorkom, moet weë gevind word waarlangs die versperring benader, en verbygesteek kan word. Die vertel van die verhaal kan slegs vernuwend en konstruerend wees indien die toekomsverhaal en die verledeverhaal in kongruensie met mekaar gebring kan word (vgl Müller 1996:30). ' $n$ Groot aantal ervare pastors wat van die narratiewe benadering gebruik maak, lê klem op die moeilikheidsgraad van hierdie proses van hervertel van die eie verhaal. Dit is nie ' $n$ goedkoop, maklike metode van werk nie, maar vereis ware persoonlike betrokkenheid, opregte luister, en diep medemenslike meelewing.

\section{4 \\ BAIE PAAIE NA ROME}

Mense is geneig om op die gevestigde roete van hulle lewensverhaal te hou. Dis gerieflik, dis veilig, dit werk. Tot op 'n dag dat hulle ten opsigte van hierdie bekende pad, in " $n$ krisis beland. "Crisis situations are the turning points where the story-line of the personal narrative has to be changed in order to arrive at a meaningful interpretation" (Ganzevoort 1993:279). Die pastor moet by die spesifieke plek waar die pyn is, help soek na " $n$ "ompad" wat meer uitsig, uitdaging en geleenthede bied. Dit vind plaas deur te herformuleer, om ' $n$ ander raam te suggereer waarmee dit moontlik word om ' $n$ bepaalde verhaal anders te vertel. Omdat ons werklikheid " $n$ deur - taal-gekonstrueerde werklikheid is, speel taal in herformulering ' $n$ baie belangrike rol. Gerkin (1986:5) skryf: "By language we make sense out of what we experience". Veral by die oomblik van herformulering, is dit noodsaaklik dat pastor en individu mekaar "vind", en dat daar "n sterk "in-language" (Anderson \& Goolishian) binding plaasvind. Dis hier, tydens die diepte-dimensie van helder herformulering, dat hervertelling begin plaasvind. Wanneer hierdie "nuwe weg" nie " $n$ deurleefde, aanvaarde en toegeëiende weg is nie, sal dit misluk. Storie, het transformerende krag net in soverre as wat dit verinnerlik en deurleefd en betekenisvol is. Bruner, soos aangehaal deur Freedman en Combs (1996:88) skryf: "stories become transformative only in their performance".

\section{OM TE DROOM: TOEKOMS EN MOONTLIKHEID}

Met "droom" verwys ons nie na die beelde wat "n mens "sien" terwyl jy slaap nie, maar eerder na die vemoë om dinge voor te stel in jou gedagtes. Hermans (1995:111) skryf oor verbeelding: "It represents the specific human capacity to enlarge systems of meaning beyond the limits of the world that is defined as factual". Verbeelding vorm " $n$ uiters belangrike 
deel van die narratiewe konstruksie van ons leefwêreld. Selfs wanneer ons stil is, kommunikeer ons met ons gewete, ons spieëlbeeld, ' $n$ karakter in ' $n$ film, ons ouers of kinders en vriende. Met oop of toe oë, is die brein in staat om beelde, voorstellings te "sien". Dit kan dinge uit die verlede wees, of denkbeeldige, toekomsgerigte voorstellings. "Narrative organizes our fantasies and daydreams, our unvoiced stories, our plans and memories, even our loving and hating" (Hermans, in Hermans \& Jansen 1995:6). Ons oriëntasie ten opsigte van verlede en toekoms gee sin aan ons bestaan in die hede. ' $n$ Disoriëntasie van verlede òf toekoms gee aanleiding tot ongemak en selfs krisis. "n Helder toekomsverwagting, wat gestalte kry in 'n duidelike tockomsgerigtheid met doelwitte, is van groot belang vir ons identiteit sowel as vir ons motivering vir die lewe. Jordaan (1989:669) verwys na Seneca wat gesê het: "As jy nie weet na watter hawe jy seil nie, is daar geen wind wat vir jou reg sal waai nie". Wat in gedagte gehou moet word, is dat daar " $n$ groot verskil is tussen die beelde of voorstellings uit die verlede, soos herroep deur geheue, en dié wat ons toekomsdrome uitmaak. "Those recollected are capable of high definition, a large measure of completeness. An image of the future is vague and sketchy, a story incomplete and thin" (Crites 1986:164).

Hoewel toekomsdrome nie met presiese akkuraatheid voorgestel kan word nie, het dit tog ' $n$ heelheid in die hede. Die hede staan nooit stil nie en is gedurig op die toekoms gerig. Die huidige, die oomblik, is so pas verby en die hede leun vorentoe, die toekoms in. Lester (1995:14) skryf: "Past, present and future are for the human mind and heart the three dimensions or directions into which the human sense of time extends and which in their togetherness constitute the present moment". Crites (1986:163) gebruik die voorstelling van die pianis wat besig is om klavier te speel. Sekere note is reeds gespeel en sterf weg in die verlede in, hoewel hulle klank nog in herrinnering 'gehoor' kan word. Ander note word in die hede gespeel, en die pianis se oë is reeds ' $n$ paar note vooruit op die bladmusiek gevestig. Saam vorm die reeds gespeelde note, dié wat tans opklink sowel as dié wat nog moet kom, die melodie. Dit is die verband tussen die verlede en die toekoms wat in die hede die belangrike deurslag vir betekenis en verstaan verskaf. Die toekoms word die reeds-teenwoordige en die verlede word die steeds-teenwoordige in die verhale wat ons vertel. Die toekoms en die verlede word tot ' $n$ spanningsvolle en kragtige NOU (vgl Müller 1998:5).

' $n$ Verdere verhelderende beeld van Crites (1986:164) is die van die argeologiese uitgrawing. Die argeoloog werk en grawe dic toekoms in, maar hoe meer hy van die verlede wil weet, hoe verder moet hy die toekoms in grawe. Die verlede kan net onthou word, dit is vir goed verby en daar kan niks meer aan gedoen word nie. In die toekoms lê die potensiaal van verandering, wat so noodsaaklik is in die pastorale gesprek. "Future tense is the time for metamorphosis" (Crites 1986:165). En volgens 
Crites is dit Kierkegaard wat gesê het: "We understand backwards, but we live forwards".

Dit is hierdie tweerigting beweging wat ter sprake kom in die pastorale ontmoeting. "In negotiating that extraordinary double movement there is both danger and opportunity" (Crites 1986:165). Die gevaar is dat daar op grond van baie negatiewe herinneringe voor ' $n$ uitsiglose, bedreigende en hooplose toekoms te staan gekom word. Dit vorm egter ook ' $n$ geleentheid van lewende hoop, 'n toekoms met uitdagings, geleenthede en verwagting. "God se toekoms word nie beskryf in terme van 'n bly-voortbestaan nie, maar in terme van ' $\mathrm{n}$ kom-uit-die-toekoms; nie ' $n$ beweging na die toekoms toe nie. maar " $n$ beweging uit die toekoms na die hede" (Müller 1996:133,134). Dit is ook teologies verantwoordbaar om te sê dat verandering vanuit die toekoms, en nie vanuit die verlede nie, plaasvind. Beweging, dis tog waaroor dit in die lewe gaan. Die tier spring, Oom Andries skiet. Die veer voor die neus van die sterwende. Dis tog lewe! En in lewe word gesoek na betekenis. Daarom het stories en lewe en verstaan ontsettend baie in gemeen. "Living, grasping, telling and then living again: these are the four 'movements' of the human story and of the divine story" (Hearne 1984:34). Die hantering van die dubbel beweging, van die verlede, na die toekoms, en uit die toekoms na die hede, is deurslaggewend. Die horlosiemakers van ouds, wat kronologiese tyd sirkulêr voorgestel het, het waarskynlik iets hiervan verstaan. Het ons lewe, ook ons geestelike lewe, nie meer met sirkulariteit te doen as wat ooit voorheen vermoed is nie? Lê die beweging van die aarde om die son, swaartekrag, lig en donker, nie ten grondslag van die lewe nie?

\section{OM TE DROOM EN GELOOF}

Die Christelike geloof handel oor sekerheid oor die dinge wat ons nie sien nie (Heb 11:1). Mens sou kon sê dat die woord wat die naaste daaraan kom om te vertel wat geloof is - die begrip hoop is. "...faith, in the opinion of some modern writers, can best be described as hope, as courage, as a bold opinion for life and renewal" (Hearne 1984:40). Geloof handel juis oor Hom wat nie gesien word nie, en tog op sy Woord geneem kan word. In Johannes 20:29b sê Jesus: "Gelukkig is die wat nie gesien het nie, en tog glo. Ons as gelowiges mag in die verwagting leef dat God dit vir ons ten goede sal laat afloop. Reeds die Ou Testament is vol daarvan, byvoorbecld in Jeremia 29:11, "Ek weet wat Ek vir julle beplan, sê die Here: voorspoed en nie teenspoed nie; Ek wil vir julle "n toekoms gee , "n verwagting"! En in die groot hoofstuk oor geloof, Hebreërs 11, staan daar by vers 8: "Hy (Abraham) het weggetrek sonder om te weet waar hy sou uitkom". Vers 10: "...want hy het uitgesien na die stad wat vaste fondamente het en waarvan God self die ontwerper en bouer is". Dit is " $n$ duur hoop, ' $n$ lewende hoop. 
Dit het die Vader sy Seun se lewe gekos om dit vir ons as gawe te bewerkstellig. Van ons vra dit hartgrondige berou oor ons sonde, bekering en ' $n$ lewe van toewyding en dankbaarheid aan die Gewer van die lewende hoop. Christus se lewe was volmaak. Sy lewe het kom doen wat dit bedoel was om te kom doen. Dit was ' $n$ lewe van oordrag van lewe, deur lyding en dood tot lewe.

Ons lewe is ook ' $n$ oordrag, van gister na nou na môre. In hierdie proses van oordrag, speel die vertel van ' $n$ verlede, en die droom van ' $n$ nuwe toekoms, in wisselwerking met mekaar, ' $n$ deurslaggewende, lewensveranderende en genesende rol.

"If the basic pattern of human life is that of "passover" from past to future, from temporal to eternal, from the self to the other, from idolatry to worship, then we should expect to find this enacted, dramatized, symbolized, expressed in all human stories, myths, drama, ritual, poetry. Telling stories is not, therefore, just a way of 'passing time' or putting children to sleep; it is how we explore together the mystery of time and of mortality, and it is a means of examining the unique journey of life. Stories bring together memory ("once upon a time') and anticipation ('and they lived happily ever after')" (Hearne 1984:38).

\section{Literatuurverwysings}

Brueggemann, W 1981. The Prophetic Imagination. Philadelphia: Fortress Press.

-, 1985. David's Iruth. In Israel's Imagination and Memory. Philadelphia: Fortress Press.

-, 1993. The Bible and Postmodern Imagination. Texts Under Negotiation. London: SCM Press.

-, 1993. Biblical Perspectives on Evangelism. Nashville: Abingdon Press.

Crites, S 1986. Story Time: Recollecting the Past and Projecting the Future. New

York/Westport/Connecticut/London: Praeger.

Finansies en Tegnick. 9 Julie 1999. KPGM Advertensie, Sandton: Gert Marais Uitgewers, p34.

Freedman, J \& Combs, G 1996. Narrative Therapy. The Social Construction of Preferred Realities. New York/London: W W Norton \& Company.

Freeman, M. 1993. Rewriting the self. History. Memory; Narrative. London and New York: Routledge.

Ganzevoort, R R 1993. "Investigating life-stories: Personal Narratives in Pastoral Psychology". Journal of Physcology' and Theology, 21.

Goudzwaard, B 1999. Hoe om sin te maak van die Postmodernisme. Kaapstad: Internos 1999(2).

Haronian, F 1976. "Phychosynthesis: A Psychotherapist's Personel Overview". Pastoral Phycology, 25.

Hearne, B 1984. "God's story in our story". Afer, 26. 
Hermans, H J M 1987. "The Dream in the Process of Valuation: A Method of Interpretation". Journal of Personality and Social Phycology, 53(1).

-, 1992. "Telling and Re-telling One's Self-narrative: A Contextual Approach to Life-span Development". Human Development, 35.

Hermans, H J M \& Hermans-Jansen, E 1995. Self-Narratives. New York: Guildford Press.

Hoskins, M \& Leseho, J 1996. "Changing Metaphors of the Self-Implications for Counseling". Journal of Counselling \& Development, 74.

Hoyt, A L F 1994. Constructive Therapies. New York/London: The Guilfbrd Press.

Jensen, M 1984. "Some Implications of Narrative Theology for Ministry to Cancer Patients. Journal of Pastoral Care, 38.

Jordaan, J \& Jordaan, J 1989. Mens in Konteks. Isando, Lexicon Uitgewers.

Lester, A D 1995. Hope in Pastoral Care and Counseling. Louisville, Kentucky: Westminster John Knox Press.

Müller, J C 1996. Om tot verhaal te kom. Pastorale gesinsterapie. Pretoria: Raad vir Geesteswetenskaplike Navorsing.

-, 2000. Reis-geselskap. Die kund van narratiewe pastorale gesprekvoering. Wellington: Lux Verbi-BM.

Müller, J C \& Maritz, B 1998. "Die waarde van metafore binne die hermeneutiespastorale sisteem". Praktiese Teologie in Suid-Afrika, 13(1). Universiteit van Pretoria.

Robertson, B 1990. "Storytelling in Pastoral Counseling. A Narrative pastoral theology". Pastoral Phycology, 39(1).

Rosenwald, G C \& Ochberg, XL 1992. Stories Lived. New Haven and London: Yale University Press.

Sarbin, I L 1986. Narrative psychology. The Storied Nature of Human Conduct. New York/Westport/Connecticut/London: Praeger.

Veldsman, D P 1993. "Religieuse ervaring as ' $\mathrm{n}$ herinneringsvolle verbeelding". Scriptura 46.

Vitz, P C 1992. "Narratives and Counseling, Part 2: From analysis of the past to stories about it". Journal of Phycology and Theology, 20(1).

Webb-Mitchell, B 1995. "The Importance of Stories in the Act of Caring". Pastoral Phychology, 43(3). 